\title{
A company experience of the first MoCA pilot project
}

\author{
Wills Hughes-Wilson \\ From 7th European Conference on Rare Diseases and Orphan Products (ECRD 2014)
}

\section{Background}

Pricing and reimbursement authorities often lack sufficient information to decide about Orphan Medicinal Products (OMPs), because of pricing, high levels of uncertainty and small datasets, amongst others. EU Member States share similar challenges as they seek to include OMPs appropriately in their healthcare systems.

The "Process on Corporate Responsibility in the field of Pharmaceuticals", launched in 2010 under the Belgium EU Presidency, included a project on a "Mechanism of Coordinated Access to Orphan Drugs" (MoCA), to explore whether a collaborative approach could create opportunities for more timely, sustainable and equitable access to OMPs. Twelve EU Member States, industry, patients' representatives and other stakeholders developed a potential mechanism for such cooperation in the MoCA Recommendations. EU Member States adopted these as part of the formal conclusions of the Process on Corporate Responsibility on 17 April 2013. The Recommendations identified points where voluntary cooperation could smooth the process of evaluation, by sharing information and data along a coordinated, dialogue-based pathway; as well as a first draft "Transparent Value Framework" (TVF) to provide a possible structure for national pricing and reimbursement discussions.

\section{From theory to practice: the MoCA pilot projects}

The Medicines Evaluation Committee of the European Social Insurance Platform (MEDEV) initiated pilot projects in July 2013. Companies were invited to participate with OMPs at any stage of development, with the objective of testing the different elements in the Recommendations. Sobi signalled its interest to participate.

Seven EU Member States volunteered to join the collaboration, together with European Organisation for Rare Diseases (EURORDIS) and two patient groups

\footnotetext{
Sobi, SE-112 76 Stockholm, Sweden
} 
Sobi experienced the MoCA as an important and highly relevant forum, providing the opportunity for managed, prospective, multi-stakeholder, trust-based dialogue, which progressively reduces uncertainty and allows sponsors to "design-in" payer-driven elements into development programmes and availability. It is based on voluntary participation of all participants so is highly flexible. It gives national payer bodies information to help them in their national providing and reimbursement decisions.

\section{Conclusions}

The first pilot was a success in testing the practical elements of a collaborative dialogue. Further projects will further test the Recommendations and the MoCA's ability to contribute to access to OMPs timely, equitably and sustainably. The participants in the MoCA pilot are planning to write up their experiences with an aim to publish their joint findings to date.

Published: 11 November 2014

doi:10.1186/1750-1172-9-S1-O26

Cite this article as: Hughes-Wilson: A company experience of the first MoCA pilot project. Orphanet Journal of Rare Diseases 2014 9(Suppl 1):O26.
Submit your next manuscript to BioMed Central and take full advantage of:

- Convenient online submission

- Thorough peer review

- No space constraints or color figure charges

- Immediate publication on acceptance

- Inclusion in PubMed, CAS, Scopus and Google Scholar

- Research which is freely available for redistribution

Submit your manuscript at www.biomedcentral.com/submit
C Biomed Central 